\title{
Metals-induced functional stress in sulphate-reducing thermophiles
}

\author{
Ali Hussain ${ }^{1}$ Javed Iqbal Qazi ${ }^{2}$
}

Received: 30 May 2015 / Accepted: 22 July 2015/Published online: 9 January 2016

(c) The Author(s) 2016. This article is published with open access at Springerlink.com

\begin{abstract}
All toxic metals have been known to inhibit different activities of sulphate-reducing bacteria (SRB) at different concentrations. The present study delineates functional responses of two thermophilic SRB species (Desulfotomaculum reducens-HA1 and Desulfotomaculum hydrothermale-HA2) to toxic metals. Bacterial activity was assessed in terms of sulphate reduction and metal precipitation employing four concentrations $(1,5,10$ and $15 \mathrm{ppm})$ of three dissolved toxic metals $(\mathrm{Cu}, \mathrm{Cr}$ and $\mathrm{Ni}$ ) independently. Both sulphidogenic bacterial species showed results in a very narrow range of fluctuations. In general, bioprecipitation and sulphate reduction were pronounced at lower concentrations ( 1 and $5 \mathrm{ppm}$ ) and got inhibited at higher concentrations (10 and $15 \mathrm{ppm}$ ). The order of precipitation and sulphate reduction for the subject metals was $\mathrm{Ni}>\mathrm{Cr}>\mathrm{Cu}$. The findings of this study will be helpful in developing economical and environmental friendly bioremediation process(es) tending to operate at extreme conditions around the concentrations in indicated suitable metals-loaded effluents.
\end{abstract}

Keywords Bioprecipitation - Economical bioremediation - Metallic pollutants $\cdot$ Sulphate-reducing bacteria $\cdot$ Thermophiles

Ali Hussain

alihussainpu@yahoo.com

1 Department of Wildlife \& Ecology, University of Veterinary and Animal Sciences, Lahore, Pakistan

2 Department of Zoology, University of the Punjab, Lahore, Pakistan

\section{Introduction}

A plenty of multidimensional anthropogenic activities especially associated with mining and other industrial processes are introducing metals continuously into the environment. Direct and indirect deleterious effects of metal ions to the environment and human health are well known (Goyer and Clarkson 2001; Landis and Yu 2004; Kucukatay et al. 2007; Mortazavi and Jafari-Javid 2009; Becker et al. 2010; Si et al. 2015). Therefore, treatment of these metallic pollutants is much necessary before discharging them to the environment. The most widely used method for the removal of metals' ions is chemical neutralization and being expensive and possible generation of secondary pollutants, its application is question marked (Saeed and Iqbal 2003; Rocha et al. 2009). Biological treatment of metal-loaded effluents is an attractive alternative. The major advantages of the biological methods are their better performance, low operational cost, minimum generation of secondary pollutants and environmentally compatible natures (Malik 2004; Okoh and Trejo-Hernandez 2006). Implication of dissimilatory sulphate-reducing bacteria (DSRB) in detoxifying metal contaminated environments has gained importance among all the biological methods practiced for the removal of metals in the last decade (Neculita et al. 2007; Martins et al. 2009; Alexandrino et al. 2011; Barbosa et al. 2014).

SRB make morphologically and physiologically a diverse group of strict anaerobes. Under anaerobic conditions, they dissimilate sulphate to sulphide while utilizing various types of low molecular weight substrates (including various environmental contaminants) as source of carbon and energy (Willis et al. 1997; Hussain and Qazi 2012, 2014; Hussain et al. 2014a, b). The biogenic sulphide, thus produced, reacts vigorously with certain metals dissolved 
in contaminated waters forming sparingly soluble metal sulphides (White et al. 2003; Costa and Duarte 2005; VegaLópez et al. 2007; Jameson et al. 2010) and, as a result, the concentrations of sulphates and dissolved metals are reduced.

Heavy metals are generally more or less toxic to all types of microorganisms including SRB (Sani et al. 2001; Cabrera et al. 2006). The toxic concentrations of heavy metals to SRB range from a few ppm to as much as $100 \mathrm{ppm}$ (Utgikar et al. 2002). The resistance of SRB to certain metals varies with the species and depends on the concentration of the metal in solution, which can be bacteriostatic or bactericidal. Therefore, a search for metal resistant SRB is much important for the development of efficient bioremediation processes based on the use of these bacteria (Martins et al. 2009).

During the last three decades, a thorough research has been made to decode almost all modes of microbial metal interactions in mesophilic microorganisms for their capable and powerful applications in various bioremediation processes, while the potency of thermophilic microorganisms has largely been unexplored. Thus, thorough and concentrated inquiries on thermophilic microbial metal resistance and their different ways of metal mutual actions can enrich our present knowledge for the improvement of metal bioremediation strategies (Hetzer et al. 2006; Poli et al. 2009; Chatterjee et al. 2010; Sheoran et al. 2010; Ozdemir et al. 2012).

The above highlighted facts reinforce the primary consideration of thermophilic microbial metal interactions at all levels including characterization of inhabitant thermophilic microorganisms and their modes of interactions with metals for designing bioremediation strategies associated with high temperature and other stressful factors. Adequate literature is available on the interaction of mesophilic SRB with toxic metals. However, data on the thermophilic sulphate-reducing bacterial interactions with metals are quite meagre. Pertaining to the context, the present study was designed to probe into the effect haphazardly chosen three toxic metals $(\mathrm{Cu}, \mathrm{Cr}$ and $\mathrm{Ni})$ on two thermophilic SRB species.

\section{Materials and methods}

\section{Sampling and chemical characterization}

The water samples were recovered from a hot water spring in Chakwal District $\left(32.55^{\circ} \mathrm{N} 72.51^{\circ} \mathrm{E}\right)$, Pakistan. The $\mathrm{pH}$ and temperature of the water at the time of sampling were 8 and $53{ }^{\circ} \mathrm{C}$, respectively. Multielemental analysis of the collected samples (Table 1) was carried out by proton-induced X-ray emission (PIXE). Then physicochemical
Table 1 Physicochemical and multielemental analyses of the samples

\begin{tabular}{|c|c|c|}
\hline Parameter & Sample 1 & Sample 2 \\
\hline Electrical conductivity $\left(\mathrm{Sm}^{-1}\right)$ & 19.8 & 14.6 \\
\hline $\mathrm{CO}_{3}^{2-}\left(\mathrm{meqL}^{-1}\right)$ & 0.00 & 1.3 \\
\hline $\mathrm{HCO}_{3}{ }^{1-}\left(\mathrm{meqL} \mathrm{L}^{-1}\right)$ & 3.8 & 4.2 \\
\hline $\mathrm{Cl}^{1-}\left(\mathrm{mgL}^{-1}\right)$ & 540 & 498 \\
\hline $\mathrm{SO}_{4}{ }^{2-}\left(\mathrm{mgL}^{-1}\right)$ & 307 & 109 \\
\hline \multicolumn{3}{|c|}{ Element (Concentration in $\mathrm{gKg}^{-1}$ ) } \\
\hline As & 0.007 & 0.019 \\
\hline $\mathrm{Ba}$ & 0.443 & 0.474 \\
\hline $\mathrm{Ca}$ & 31.42 & 27.57 \\
\hline $\mathrm{Cd}$ & 0.009 & 0.008 \\
\hline $\mathrm{Cr}$ & 0.013 & 0.018 \\
\hline $\mathbf{C u}$ & 0.009 & 0.019 \\
\hline $\mathrm{Fe}$ & 5.156 & 4.795 \\
\hline $\mathrm{K}$ & 19.17 & 11.62 \\
\hline $\mathbf{N i}$ & 0.001 & 0.002 \\
\hline $\mathrm{Pb}$ & 0.004 & 0.013 \\
\hline $\mathrm{Sb}$ & 0.008 & 0.009 \\
\hline $\mathrm{Se}$ & 0.001 & 0.002 \\
\hline Sn & 0.001 & 0.001 \\
\hline $\mathrm{Ti}$ & 0.936 & 0.611 \\
\hline $\mathrm{V}$ & 0.071 & 0.043 \\
\hline $\mathrm{Zn}$ & 0.063 & 0.137 \\
\hline
\end{tabular}

Metals relevant to this study are shown in bold

parameters including electrical conductivity (EC), carbonates $\left(\mathrm{CO}_{3}{ }^{2-}\right)$, bicarbonates $\left(\mathrm{HCO}_{3}{ }^{1-}\right)$, chlorides $\left(\mathrm{Cl}^{1-}\right)$ and sulphates $\left(\mathrm{SO}_{4}{ }^{2-}\right)$ of the collected samples were measured prior to its further processing for isolation of SRB (Table 1). EC was measured with the help of a digital conductivity meter (UK). $\mathrm{CO}_{3}{ }^{2-}, \mathrm{HCO}_{3}{ }^{1-}$ and $\mathrm{Cl}^{1-}$ were measured following standard protocols (APHA 2005) while $\mathrm{SO}_{4}{ }^{2-}$ was estimated after Cha et al. (1999).

\section{Initial enrichments and isolation of thermophilic SRB}

The collected samples were then enriched anaerobically in Postgate B medium. Compositions of different media used in this study are shown in Table 2. All enrichments were made after Hussain and Qazi (2012) by seeding $10 \%$ samples in sterilized serum bottles of $20 \mathrm{~mL}$ capacity under anaerobic conditions. The inoculated bottles were incubated at $55^{\circ} \mathrm{C}$ till blackening of the medium. SRB growth was confirmed by the formation of black precipitates in addition to production of rotten egg smell of $\mathrm{H}_{2} \mathrm{~S}$. Production of $\mathrm{H}_{2} \mathrm{~S}$ was detected by smelling the gas which was obtained from the head space of inoculated vials with 
Table 2 Compositions of various media used in this study

\begin{tabular}{llllr}
\hline Ingredient & \multicolumn{2}{l}{ Concentration in $\mathrm{gL}^{-1}$} & Reference \\
\cline { 2 - 4 } & $\begin{array}{l}\text { Medium } \\
\text { B }\end{array}$ & $\begin{array}{l}\text { Medium } \\
\mathrm{C}\end{array}$ & $\begin{array}{l}\text { Medium } \\
\mathrm{E}\end{array}$ & \\
\hline $\mathrm{KH}_{2} \mathrm{PO}_{4}$ & 0.5 & 0.5 & 0.5 & Postgate \\
$\mathrm{NH}_{4} \mathrm{Cl}$ & 1.0 & 1.0 & 1.0 & $(1984)$ \\
$\mathrm{CaSO}_{4}$ & 1.0 & - & - & \\
$\mathrm{MgSO}_{4} \cdot 7 \mathrm{H}_{2} \mathrm{O}$ & 2.0 & 0.06 & - & \\
$\mathrm{FeSO}_{4} \cdot 7 \mathrm{H}_{2} \mathrm{O}$ & 0.5 & - & 0.5 & \\
$\mathrm{Na}_{2} \mathrm{SO}_{4}$ & - & 4.5 & 1.0 & \\
$\mathrm{CaCl}_{2} \cdot 6 \mathrm{H}_{2} \mathrm{O}$ & - & - & 1.0 & \\
$\mathrm{MgCl}_{2} \cdot 7 \mathrm{H}_{2} \mathrm{O}$ & - & - & 2.0 & \\
$\mathrm{Sodium} \mathrm{lactate}$ & $3.5 \mathrm{~mL}$ & $6.0 \mathrm{~mL}$ & 3.5 & \\
Yeast extract & 1.0 & 0.25 & 1.0 & \\
Ascorbic acid & 0.1 & - & 0.1 & \\
Thioglycolic acid & $0.1 \mathrm{~mL}$ & - & 0.1 & \\
Agar & - & - & 15.0 & \\
\hline
\end{tabular}

the help of sterile insulin syringes. These enrichments were used to isolate pure cultures of the SRB.

The seed thermophilic SRB were then isolated and pure cultured by repeated application of deep-agar dilution method (dilution-to-extinction method) after Postgate (1984) from water samples using Postgate E medium. pH of the medium was initially adjusted to 7.6 with $1 \mathrm{M} \mathrm{NaOH}$ solution. Bacterial pure cultures obtained thus, were maintained in sterile, air-tightened and screw-capped glass bottles filled with Postgate B medium having pH between 7.0 and 7.5 and stored in a dark cupboard at room temperature in Microbial Biotechnology Laboratory, University of the Punjab, Lahore, Pakistan for further experiments.

\section{Molecular characterization of the bacterial isolates}

Characterization of the bacterial isolates at the molecular level involved extraction of total genomic DNA from freshly grown cells of the bacterial isolates in Postgate B medium after Hussain et al. (2014b). 16S rRNA genes were amplified using the universal primers $27 \mathrm{f}$ ( $5^{\prime}$-AGAGTTTGATCMTGGCTCAG-3') and 1492r (5'-GGTTACCTTGT TACGACTT- $3^{\prime}$ ), which amplify a $1.5 \mathrm{~kb}$ fragment. PCR was performed in $50 \mu \mathrm{L}$ total reaction volume. The reaction mixture used for PCR amplification contained $5 \mu \mathrm{L}$ of DNA extract, $5 \mu \mathrm{L}$ of $\mathrm{MgCl}_{2}(25 \mathrm{mM}), 5 \mu \mathrm{L}$ of dNTPs $(1 \mathrm{mM}), 5 \mu \mathrm{L}$ of each primer $(5 \mathrm{pmol}), 2 \mathrm{U} / \mathrm{mL}$ of DNA Taq polymerase, $5 \mu \mathrm{L}$ of $1 \mathrm{X} \mathrm{Taq}$ buffer and $18 \mu \mathrm{L}$ of DNA free water. PCR amplification was carried out in a thermal cycler (Hamburg 22331, Germany) with a denaturation cycle for 3 min at $94{ }^{\circ} \mathrm{C}$ following 35 cycles of denaturation for $30 \mathrm{~s}$ at $95{ }^{\circ} \mathrm{C}$, annealing step of $2 \mathrm{~min}$ at $60{ }^{\circ} \mathrm{C}$ and 1 min extension at $72{ }^{\circ} \mathrm{C}$ with a final extension step of
30 min at $72{ }^{\circ} \mathrm{C}$. The PCR products obtained in this way were separated on $1 \%(\mathrm{w} / \mathrm{v})$ agarose gel stained with ethidium bromide in TAE buffer by electrophoresis and purified using Gene Purification Kit (Fermentas) following the manufacturer instructions. The amplicons were then got sequenced using Big Dye Terminator v3.1 cycle sequencing ready reactions (Macrogen, Korea) at the DNA Sequencing Facility, Korea. 16S rRNA gene sequences were assembled with phrap (version 0.990319). Homology searches were performed using BLAST (http://www.ncbi. nlm.nih.gov/BLAST/). The 16S rDNA sequences determined in this way were submitted to GenBank for obtaining accession numbers.

\section{Effect of heavy metals on functioning of the bacteria}

Bacterial activity/functioning in terms of sulphate reduction and consequent precipitation of metals (bioprecipitation) was assessed using different concentrations (1, 5, 10 and $15 \mathrm{ppm})$ of three toxic metals $(\mathrm{Cu}, \mathrm{Cr}$ and $\mathrm{Ni}$ that were prepared using $\mathrm{CuSO}_{4}, \mathrm{Cr}_{2}\left(\mathrm{SO}_{4}\right)_{3}$ and $\mathrm{NiSO}_{4}$, respectively). All experiments for this purpose were performed in batch and in anaerobic conditions.

\section{Batch experiments}

These were performed in triplicates in sterile serum bottles of $20 \mathrm{~mL}$ capacity using modified Postgate $\mathrm{C}$ medium. $\mathrm{pH}$ of the medium was adjusted to $7.5 \pm 0.5$. The medium was used with supplementations of predefined concentrations $(1,5,10$ and $15 \mathrm{ppm})$ of $\mathrm{Cu}, \mathrm{Cr}$ and $\mathrm{Ni}$ independently. Metal solutions were autoclaved separately before adding them to the autoclaved and cooled medium. Sodium lactate was served as growth substrate in these experiments. The inoculum size used was $5 \%(\mathrm{v} / \mathrm{v})$ harbouring around $1.7 \times 10^{6}$ C.F.U./mL. $\mathrm{pH}$ of the medium was adjusted to $7.5 \pm 0.5$ for each experiment. Vials with different concentrations $(1,5,10$ and $15 \mathrm{ppm})$ of these three metals but without inocula served as control. Diffusion of oxygen in inoculated media was prevented by adding a layer of autoclaved and cooled liquid paraffin (about 3-5 mm thick). The inoculated bottles were sealed with fine rubber stoppers and aluminium crimp seals not allowing any air to be trapped in and incubated at $55^{\circ} \mathrm{C}$ for 15 days.

\section{Sampling and analytical methods}

Periodically (after every 5 days), $5 \mathrm{~mL}$ sample from each incubated vial was withdrawn with the help of a sterile syringe and filtered using a fine quality filter paper (Whatman Cat No. 1001917, UK). Metals and $\mathrm{SO}_{4}{ }^{2-}$ were analysed for each experiment from the withdrawn samples. For analyses of metals, the samples were acidified with 
nitric acid and then metals' concentrations were analysed through atomic absorption spectrophotometer while $\mathrm{SO}_{4}{ }^{2-}$ was estimated after Cha et al. (1999). After determining un-precipitated concentrations of the metals, bioprecipitation percentages of the metals were also calculated according to the following formula:

Bioprecipitation $(\%)=\frac{([\mathrm{M}] t=0-[\mathrm{M}] t=t) \times 100}{[\mathrm{M}] t=0}$

where $[\mathrm{M}] t=0$ is the dissolved metal concentration at initial time after inoculation and $[\mathrm{M}] t=t$ is the dissolved metal concentration at measure time.

\section{Statistical analysis}

The data were analysed according to Completely Randomized Design (CRD) under factorial arrangement using General Linear Model (GLM) procedures. Means were separated out using Duncan's Multiple Range (DMR) test with the help of SAS 9.1 for windows (Cary 2002). Differences between means were considered significant at $P<0.05$.

\section{Results}

\section{Isolation and molecular characterisation of the bacterial isolates}

Two thermophilic SRB species were isolated and pure cultured in this study. BLAST searches of $16 \mathrm{~S}$ rDNA nucleotide sequences of the bacterial isolates revealed that these bacterial species belonged to the genus Desulfotomaculum and the bacteria were identified as Desulfotomaculum reducens-HA1 and Desulfotomaculum hydrothermale-HA2. The GenBank has allotted accession numbers for these sequences as KF509892 and KF509893, respectively. Both of these two sulphidogenic bacterial species reduced sulphate and precipitated metals in a very close index.

\section{Effect of heavy metals on functioning of the bacteria}

In general, bioprecipitation and sulphate reduction were significant at lower concentrations ( 1 and 5 ppm) and nonsignificant at higher concentrations (10 and $15 \mathrm{ppm})$ of metals. The functioning of bacteria, thus presented an inverse relation with metal concentrations. However, bacterial functioning differed non-significantly between the two species throughout in this study. The overall order of the subject metals' toxicity to both SRB species appeared as $\mathrm{Cu}>\mathrm{Cr}>\mathrm{Ni}$. Detailed effects of different concentrations of these metals to the bacteria are described below:

\section{Effect of copper}

Precipitation of $\mathrm{Cu}$ could reach maximally to $66,38.4,3.3$ and $0.27 \%$ at $1,5,10$ and $15 \mathrm{ppm}$ of $\mathrm{Cu}$, respectively by Desulfotomaculum reducens-HA1 after completion of the incubation period. The corresponding figures for precipitation of $\mathrm{Cu}$ by Desulfotomaculum hydrothermale-HA2 were $65,38.6,4.2$ and 0.27 at $1,5,10$ and 15 ppm of $\mathrm{Cu}$, respectively (Fig. 1a-d).

The metal concentration also influenced the sulphatereducing capacity of the SRB. An increase in the metal concentration in solution led to decrease in the sulphate reduction rates. For instance, at $1 \mathrm{ppm}$ of $\mathrm{Cu}$ the maximum sulphate reduction was recorded to $24 \%$, at $5 \mathrm{ppm}$ to $15 \%$, at $10 \mathrm{ppm}$ to $2 \%$ and at $15 \mathrm{ppm}$ to $1.2 \%$ by Desulfotomaculum reducens-HA1. The corresponding figures for maximum sulphate reduction by Desulfotomaculum hydrothermale-HA2 at 1, 5, 10 and $15 \mathrm{ppm}$ of $\mathrm{Cu}$ were 23, 18, 1.7 and 1.1, respectively (Fig. 2a-d).

\section{Effect of chromium}

Chromium toxicity to both bacterial species appeared more or less similar to that of copper at $1 \mathrm{ppm}$ of $\mathrm{Cr}$. However, at relatively higher concentrations $(5,10$ and $15 \mathrm{ppm}), \mathrm{Cr}$ appeared less toxic than $\mathrm{Cu}$ as bioprecipitation and sulphate reduction were much pronounced than those of $\mathrm{Cu}$ even at these concentrations. The overall percent precipitation of $\mathrm{Cr}$ appeared as 67, 52.8, 27.8 and 15.73 at 1, 5, 10 and $15 \mathrm{ppm}$ of $\mathrm{Cr}$, respectively by Desulfotomaculum reducens-HA1. The corresponding figures for precipitation of $\mathrm{Cr}$ by Desulfotomaculum hydrothermale-HA2 were 66, 53.2, 28.6 and 17.8 at $1,5,10$ and $15 \mathrm{ppm}$ of $\mathrm{Cu}$, respectively (Fig. 1a-d).

Sulphate-reducing capacity of the both bacterial species decreased gradually as the added concentration of $\mathrm{Cr}$ increased. The order of sulphate reduction by the bacteria at different concentrations of $\mathrm{Cr}$ appeared as $1 \mathrm{ppm}>5 \mathrm{ppm}>10 \mathrm{ppm}>15 \mathrm{ppm}$. The overall sulphate-reducing efficiency of Desulfotomaculum reducensHA1 could reach maximally to $23,17,12.8$, and $8.6 \%$ at 1 , 5,10 and $15 \mathrm{ppm}$ of $\mathrm{Cr}$ while the corresponding figures for Desulfotomaculum hydrothermale-HA2 were 24, 20, 12.8, and 8.6 at the respective concentrations (Fig. 2a-d).

\section{Effect of Nickel}

In the course of bioprecipitation of $\mathrm{Ni}$, a somewhat different trend was shown by the SRB. Bioprecipitation as well sulphate reduction potentials of the bacteria appeared much better compared to those of copper and chromium even at higher concentrations (10 and $15 \mathrm{ppm})$. The percent precipitation of $\mathrm{Ni}$ reached maximally to $85,68,37.7$, 

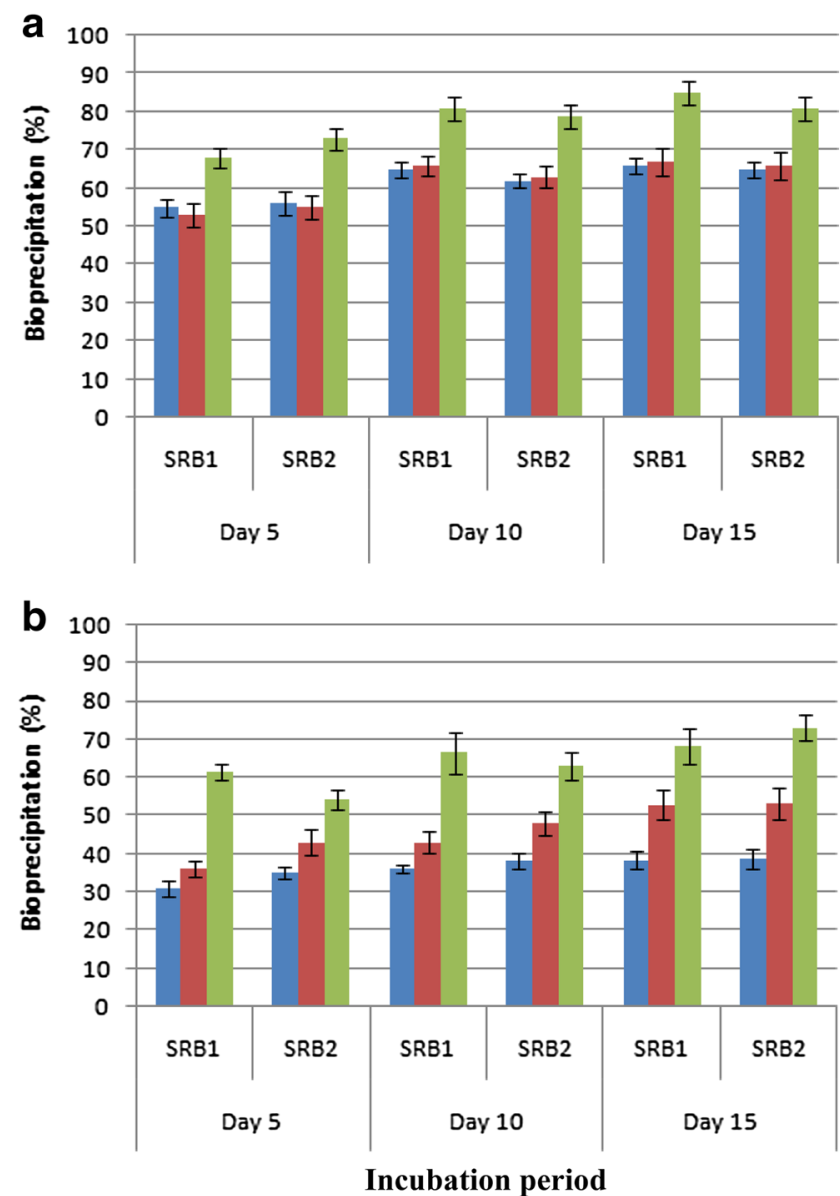

Fig. 1 Bacterial profiles of precipitation of metals $(\mathrm{Cu}, \mathrm{Cr}$ and $\mathrm{Ni})$ under anaerobic conditions at $1 \mathrm{ppm}(\mathbf{a}), 5 \mathrm{ppm}(\mathbf{b}), 10 \mathrm{ppm}$ (c) and $15 \mathrm{ppm}$ (d) of metals (blue bar $\mathrm{Cu}$, brown bar $\mathrm{Cr}$ and green bar $\mathrm{Ni}$ )

and 13 at $1,5,10$, and $15 \mathrm{ppm}$ of $\mathrm{Ni}$, respectively by Desulfotomaculum reducens-HA1. The corresponding figures for the precipitation of $\mathrm{Ni}$ by Desulfotomaculum hydrothermale-HA2 appeared as $81,73,37.2$, and 18.9 at $1,5,10$, and $15 \mathrm{ppm}$ of $\mathrm{Ni}$, respectively (Fig. 1a-d).

Sulphate reduction performances were also pronounced at all concentrations of $\mathrm{Ni}$. For instance, at $1 \mathrm{ppm}$ of $\mathrm{Ni}$ the maximum sulphate reduction was recorded to $38 \%$, at $5 \mathrm{ppm}$ to $27 \%$, at $10 \mathrm{ppm}$ to $20.1 \%$ and at $15 \mathrm{ppm}$ to $8.4 \%$ by Desulfotomaculum reducens-HA1. The corresponding figures for maximum sulphate reduction by $D e$ sulfotomaculum hydrothermale-HA2 at 1, 5, 10 and $15 \mathrm{ppm}$ of $\mathrm{Ni}$ were 37.5, 31.3, 19.2 and $10.1 \%$, respectively (Fig. 2a-d).

In all the experiments dealing with the bioprecipitations of metals $(\mathrm{Cu}, \mathrm{Cr}$ and $\mathrm{Ni}), \mathrm{pH}$ of the inoculated media remained in the neutral to slight basic range (7.0 to 8.1) till the end of anaerobic incubation. In control experiments (un-inoculated), metals' precipitation and sulphate reduction did not occur.
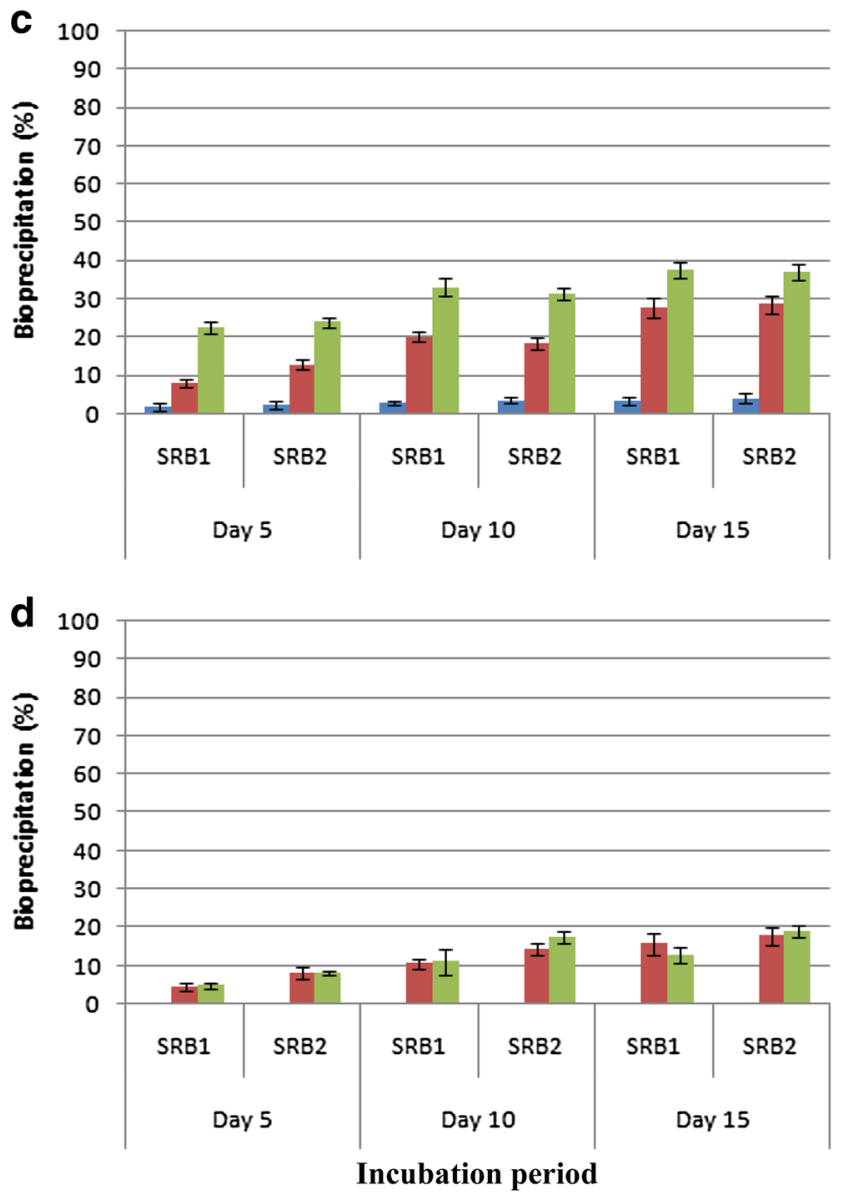

depicting toxic/inhibitory effects of metals. SRB1 and SRB2 represented Desulfotomaculum reducens-HA1 and Desulfotomaculum hydrothermale-HA2, respectively

\section{Discussion}

Both bacterial species used in this study for precipitation of the metals showed results in a very narrow range. The changes in sulphate reduction as a function of time with varying amounts of copper appeared variable. A significant decrease in sulphate reduction at $10 \mathrm{ppm}$ of copper indicated that this concentration exerted a significant inhibitory effect on the SRB cultures. This inhibition became more pronounced as the dissolved metal concentration became increased and the assays with higher levels of copper $(15 \mathrm{ppm})$ reduced the ability of SRB to precipitate the metal. These findings were consistent with those of Cabrera et al. (2006) who reported similar results while assessing precipitation of various toxic metals using two mesophilic cultures of SRB (Desulfovibrio vulgaris and Desulfovibrio sp.). Inhibition of SRB cultures by metals ( $\mathrm{Cu}$ and $\mathrm{Zn})$ in bioremediation of acid mine drainage was also reported earlier by Utgikar et al. (2002). However, in both of these two cases, mesophilic SRB cultures were employed for the 

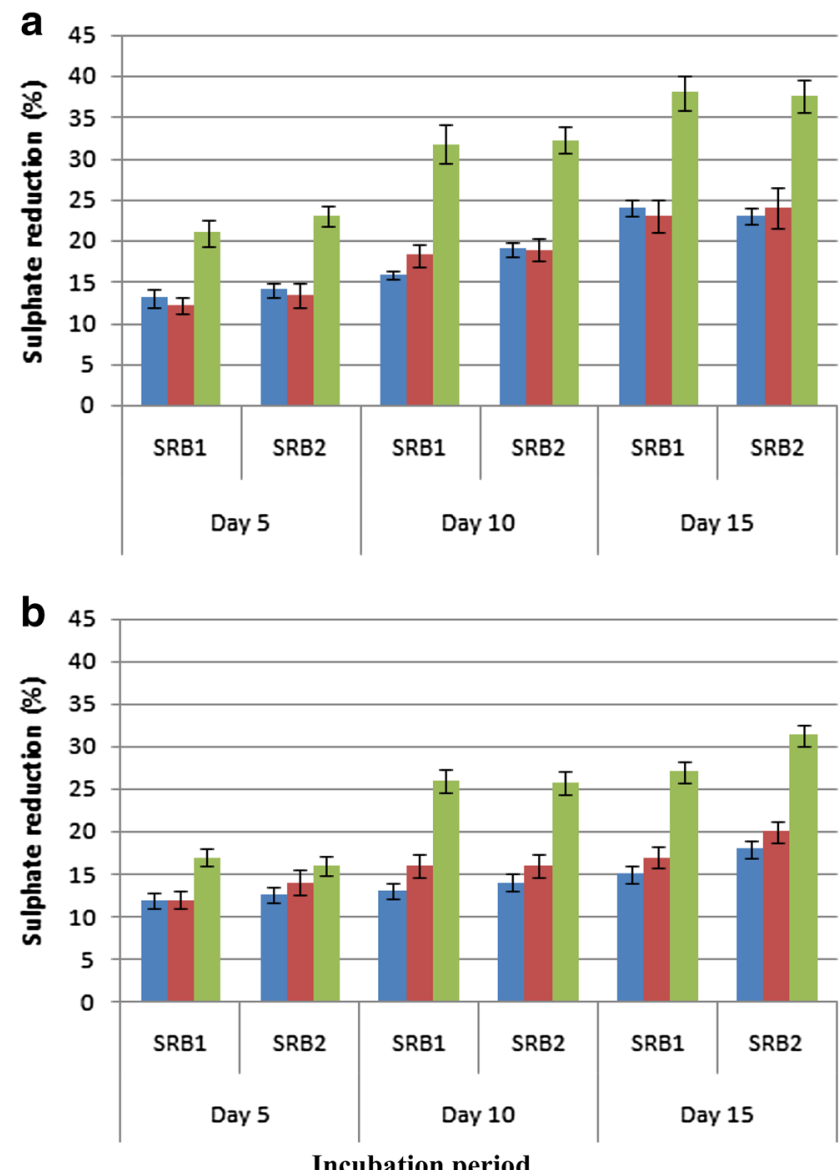

Fig. 2 Bacterial profiles of sulphate reductions under anaerobic conditions at $1 \mathrm{ppm}(\mathbf{a}), 5 \mathrm{ppm}(\mathbf{b}), 10 \mathrm{ppm}$ (c) and $15 \mathrm{ppm}$ (d) of metals (blue bar $\mathrm{Cu}$, brown bar $\mathrm{Cr}$ and green bar $\mathrm{Ni}$ ) depicting toxic/

precipitation of metals. Literature on metal precipitation potential of the thermophiles is not available to support or oppose our results of the present study.

Bioprecipitation of copper as well as sulphate reduction occurred maximally at lower concentrations of metal (1 and $5 \mathrm{ppm}$ ) and decreased retrogressively as the concentration of the dissolved metal increased (from 10 to $15 \mathrm{ppm})$. These results were in accordance with the data reported previously (Sani et al. 2001; Utgikar et al. 2003; Cabrera et al. 2006; Azabou et al. 2007; Sheng et al. 2011). Various researchers have proved the stimulatory effects of heavy metals on SRB at lower concentrations and inhibitory (causing a reduction of metabolic activity) or even toxic (causing death) at higher concentrations (Utgikar et al. 2002; Sani et al. 2003). The metal pollutants may inactivate enzymes, denature the proteins and enter in competition with essential cations (Utgikar et al. 2002). But in a study reported earlier by Alexandrino et al. (2011), SRB showed maximum tolerance and activity even at extra ordinary high concentration of copper (more than $500 \mathrm{ppm}$ ). However, those bacteria were procured from a
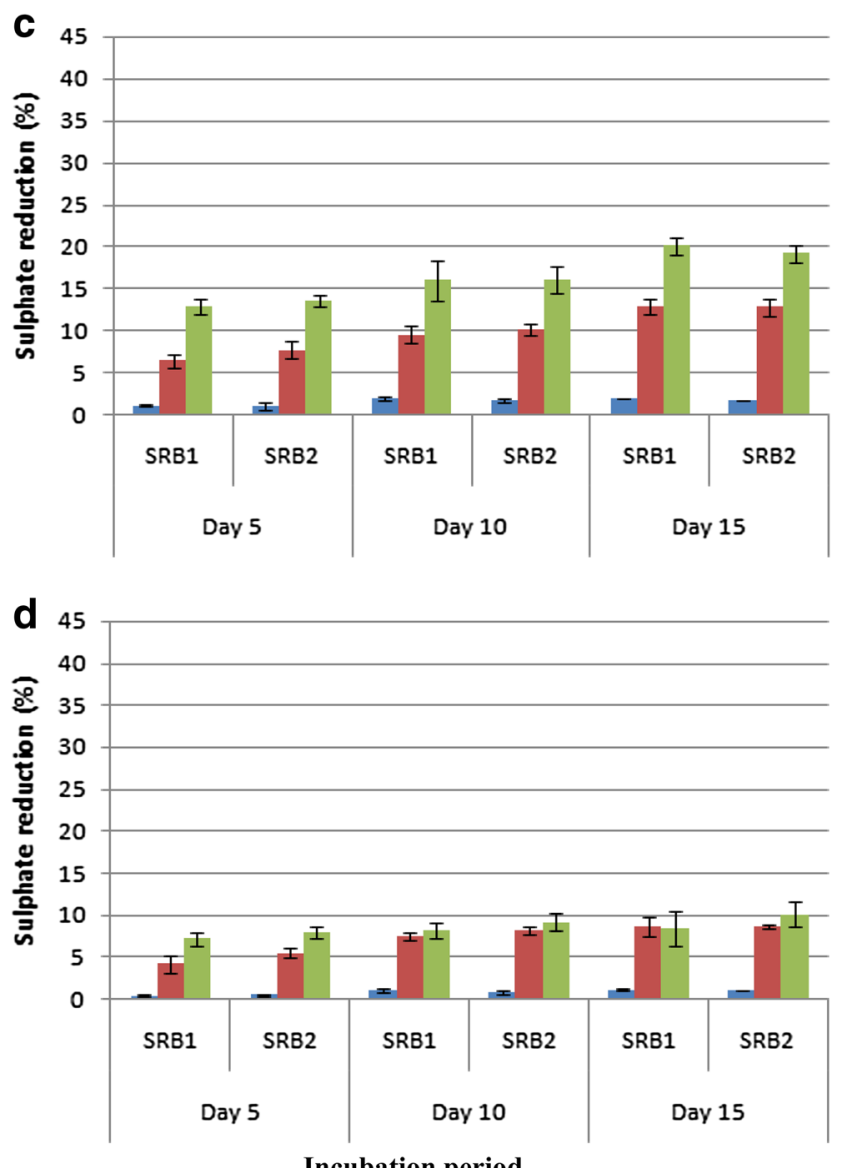

Incubation period

inhibitory effects of metals. SRB1 and SRB2 represented Desulfotomaculum reducens-HA1 and Desulfotomaculum hydrothermaleHA2, respectively

highly metal polluted environment where copper concentration was more than $1000 \mathrm{mg} / \mathrm{kg}(1000 \mathrm{ppm})$ and therefore, they must have tolerance against much higher concentrations of copper.

Chromium appeared relatively less toxic to the SRB than copper as bioprecipitation and sulphate uptake were even noted at higher concentrations (15 ppm) in this case. This finding was consistent with the previous literature values for toxic concentrations, which were lower for copper than chromium (Cabrera et al. 2006; Ahmadi et al. 2015; Verma et al. 2015). The reason for this difference in cell deactivation could be due to interactions with the bacterial cultures, although further investigations into the exact mechanisms are required to obtain a deeper understanding of this phenomenon as reported earlier by Cabrera et al. (2006).

Negative influence of nickel on the activity of the SRB remained lowest as compared to the cases of $\mathrm{Cu}$ and $\mathrm{Cr}$ showing remarkable precipitation of the metal at its higher concentration (15 ppm). In a study carried out by Cabrera et al. (2006), nickel concentrations greater than $8.5 \mathrm{ppm}$ 
exerted a marked inhibitory effect on cultures and this effect was much pronounced for certain SRB strains (Desulfovibrio vulgaris). Different isolates, especially those procured from different locations and/or by varying isolation methods do vary in their tolerance levels. This notion necessitates continuous search and isolation of microorganisms employing the suitable selective pressures to search novel microbes as well as to preserve the microbial biodiversity.

An ideal $\mathrm{pH}$ of the media used throughout in this study exhibiting neutral to basic range might have further supported precipitation of metals. SRB other than the acidophiles require a $\mathrm{pH}$ in the range of 5-8 to grow and metabolize optimally (Willow and Cohen 2003). Beyond this range, generally the rates of microbial sulphate reduction decline and the metal removal capacity is thus reduced. Low $\mathrm{pH}(<5)$ inhibits sulphate reduction and increases the solubility of metal sulphide. A pH of 5.5 or higher is however, preferred for efficient treatment in a passive bioreactor (URS 2003).

An interesting point noted in this study was that all the SRB strains showed partial precipitation of these three metals even at lower concentrations (1 and 5 ppm) while having maximum sulphate reduction activity at these concentrations. According to Martins et al. (2009) produced $\mathrm{H}_{2} \mathrm{~S}$ easily escapes as a gas during sampling being some of it not accessible to the dissolved metals and thus the precipitation of metals can never be quantitative. This information necessitates optimisation of sulphidogenesis and the metal(s) to be precipitated within tangibly designed bioreactors allowing maximum contact area and time for the $\mathrm{H}_{2} \mathrm{~S}$ and metal(s) to react. Further studies must attempt mixtures of different metal ions' precipitation to determine the order of reactions of different metals with varying concentrations of $\mathrm{H}_{2} \mathrm{~S}$ at various physicochemical set ups. Such information might pave diverse metals bioremediation ways necessitating consideration of multiple metals pollutants.

\section{Conclusions and recommendations}

Both thermophilic SRB species obtained and employed in this study showed, in general, significant precipitation of metals at their lower concentrations. Bacteria capable of more metals' tolerance as well as precipitation potentials be isolated from mining areas to achieve metals bioremediation goal efficiently.

Pure cultures of SRB were employed in the present study for detoxification of metals and sulphates. As at laboratory scale, for determining exact remedial potentials of each microbe, it is necessary to study them in pure cultures. However, the use of mixed cultures is advantageous in providing bacterial consortia that facilitate both the development of reducing conditions as well as utilization of complex nutritive substrates as various researchers have been agreed in this regard. Thus, the implication of mixed cultures of thermophiles for the efficient remediation of metals-loaded wastewaters demand further studies in future.

Acknowledgments Financial support of Higher Education Commission, Pakistan for funding the first author under the "Indigenous Ph.D. 5000 Fellowship programme" is highly acknowledged.

\section{Compliance with ethical standards}

Conflict of interest The authors report no conflicts of interest.

Open Access This article is distributed under the terms of the Creative Commons Attribution 4.0 International License (http:// creativecommons.org/licenses/by/4.0/), which permits unrestricted use, distribution, and reproduction in any medium, provided you give appropriate credit to the original author(s) and the source, provide a link to the Creative Commons license, and indicate if changes were made.

\section{References}

Ahmadi R, Rezaee A, Anvari M, Hossini H, Rastegar SO (2015) Optimization of $\mathrm{Cr}(\mathrm{VI})$ removal by sulfate-reducing bacteria using response surface methodology. Desalin Water Treat. doi:10.1080/19443994.2015.1041055

Alexandrino M, Macíasb F, Costa R, Gomesc NCM, Canárioa AVM, Costa MC (2011) A bacterial consortium isolated from an Icelandic fumarole displays exceptionally high levels of sulfate reduction and metals resistance. J Hazard Mater 187:362-370

APHA (2005) Standard methods for the examination of water and wastewater, 21st edn. APHA, Washington, DC

Azabou S, Mechichi T, Patel BKC, Sayadi S (2007) Isolation and characterization of a mesophilic bacteria heavy-metals-tolerant sulphate-reducing bacterium Desulfomicrobium sp. from an enrichment culture using phosphogypsum as a sulphate source. J Hazard Mater 140:264-270

Barbosa LP, Costa PF, Bertolino SM, Silva JCC, Guerra-Sá R, Laão VA, Teixeira MC (2014) Nickel, manganese and copper removal by a mixed consortium of sulfate reducing bacteria at a high COD/sulfate ratio. World J Microbiol Biotechnol 30:2171-2180

Becker M, Edwards S, Massey RI (2010) Toxic chemicals in toys and children's products: limitations of current responses and recommendations for government and industry. Environ Sci Technol 44:7986-7991

Cabrera G, Pérez R, Gómez JM, Ábalos A, Cantero D (2006) Toxic effects of dissolved heavy metals on Desulfovibrio vulgaris and Desulfovibrio sp. strains. J Hazard Mater 135:40-46

Cary NC (2002) Statistics Version 9.01. SAS Institute Inc, USA

Cha JM, Cha WS, Lee J-H (1999) Removal of organo-sulphur odour compounds by Thiobacillus novellus srm, sulphur-oxidizing bacteria. Process Biochem 34:659-665

Chatterjee SK, Bhattacharjee I, Chandra G (2010) Biosorption of heavy metals from industrial waste water by Geobacillus thermodenitrificans. J Hazard Mater 175:117-125

Costa MC, Duarte JC (2005) Bioremediation of acid mine drainage using acidic soil and organic wastes for promoting sulphatereducing bacteria activity on a column reactor. Water Air Soil Pollut 165:325-345

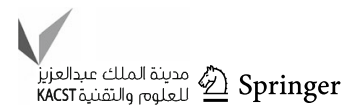


Goyer RA, Clarkson TW (2001) Toxic effects of metals. In: Klaassen CD (ed) Casarett and Doull's toxicology: the basic science of poisons. McGraw-Hill, New York, pp 811-867

Hetzer A, Daughney CJ, Morgan HW (2006) Cadmium ion biosorption by the thermophilic bacteria Geobacillus stearothermophilus and G. thermocatenulatus. Appl Environ Microbiol 72:4020-4027

Hussain A, Qazi JI (2012) Biological sulphate reduction using watermelon rind as a carbon source. Biologia (Pakistan) 58:85-92

Hussain A, Qazi JI (2014) Application of sugarcane bagasse for passive anaerobic biotreatment of sulphate rich wastewaters. Appl Water Sci. doi:10.1007/s13201-014-0226-2

Hussain A, Qazi JI, Shakir HA (2014a) Implication of molasses as electron donor for biological sulphate reduction. Am J Environ Eng 4:7-10

Hussain A, Shakir HA, Qazi JI (2014b) Anaerobic biodegradation of sulphate employing animal manure as a cost effective growth substrate. J Anim Plant Sci 24:913-918

Jameson E, Rowe OF, Hallberg KB, Johnson DB (2010) Sulfidogenesis and selective precipitation of metals at low $\mathrm{pH}$ mediated by Acidithiobacillus spp. and acidophilic sulfate-reducing bacteria. Hydrometallurgy 104:488-493

Kucukatay V, Bor-Kucukatay M, Atsak P, Ağar A (2007) Effect of ingested sulfite on hippocampus antioxidant enzyme activities in sulfite oxidase competent and deficient rats. Int $\mathrm{J}$ Neurosci 117:971-983

Landis WG, Yu M-H (2004) Introduction to environmental toxicology, 3rd edn. CRC Press/Lewis Publishers, USA

Malik A (2004) Metal bioremediation through growing cells. Environ Int 30:261-278

Martins M, Faleirob ML, Barros RJ, Veríssimo AR, Barreirosd MA, Costa MC (2009) Characterization and activity studies of highly heavy metal resistant sulphate-reducing bacteria to be used in acid mine drainage decontamination. J Hazard Mater 166:706-713

Mortazavi F, Jafari-Javid A (2009) Acute renal failure due to copper sulfate poisoning; a case report. Iran J Pediatr 19:75-78

Neculita CM, Zagury GJ, Bussière B (2007) Passive treatment of acid mine drainage in bioreactors using sulphate reducing bacteria. J Environ Qual 36:1-16

Okoh AI, Trejo-Hernandez MR (2006) Remediation of petroleum polluted systems: exploiting the bioremediation strategies. Afr J Biotechnol 5:2520-2525

Ozdemir S, Kilinc E, Poli A, Nicolaus B, Guven K (2012) Cd, Cu, Ni, $\mathrm{Mn}$ and $\mathrm{Zn}$ resistance and bioaccumulation by thermophilic bacteria, Geobacillus toebii subsp. decanicus and Geobacillus thermoleovorans subsp. stromboliensis. World J Microbiol Biotechnol 28:155-163

Poli A, Salerno A, Laezza G, Donato P, Dumontet S, Nicolaus B (2009) Heavy metal resistance of some thermophiles: potential use of alpha-amylase from Anoxybacillus amylolyticus as a microbial enzymatic bioassay. Res Microbiol 160:99-106
Postgate JR (1984) The sulfate-reducing bacteria. Cambridge University Press, Cambridge

Rocha GG, Zaia DAM, Alfaya RVD, Alfaya AAD (2009) Use of rice straw as biosorbent for removal of $\mathrm{Cu}(\mathrm{II}), \mathrm{Zn}(\mathrm{II}), \mathrm{Cd}(\mathrm{II})$ and $\mathrm{Hg}$ (II) ions in industrial effluents. J Hazard Mater 166:383-388

Saeed A, Iqbal M (2003) Bioremoval of cadmium from aqueous solution by black gram husk (Cicer arientinum). Water Res 37:3472-3480

Sani RK, Peyton BM, Brown LT (2001) Copper-induced inhibition of growth of Desulfovibrio desulfuricans G20: assessment of its toxicity and correlation with those of zinc and lead. Appl Environ Microbiol 67:4765-4772

Sani RK, Peyton BM, Jadhyala M (2003) Toxicity of lead in aqueous medium to Desulfovibrio desulfuricans G20. Environ Toxicol Chem 22:252-260

Sheng Y, Cao H, Li Y, Zhang Y (2011) Effects of sulfide on sulfate reducing bacteria in response to $\mathrm{Cu}(\mathrm{II}), \mathrm{Hg}$ (II) and $\mathrm{Cr}(\mathrm{VI})$ toxicity. Chin Sci Bull 56:862-868

Sheoran AS, Sheoran V, Choudhary RP (2010) Bioremediation of acid-rock drainage by sulphate-reducing prokaryotes: a review. Miner Eng 23:1073-1100

Si W, Liu J, Cai L, Jiang H, Zheng C, He X, Wang J, Zhang X (2015) Health risks of metals in contaminated farmland soils and spring wheat irrigated with Yellow River water in Baotou, China. Bull Environ Contam Toxicol 94:214-219

URS Report (2003) Passive and semi-active treatment of acid rock drainage from metal mines-state of the practice. Prepared for U.S. Army Corps of Engineers, Concord, Massachusetts, by URS Corporation, Portland, ME

Utgikar VP, Harmon SM, Chaudhary N, Tabak HH, Goving R, Haines JR (2002) Inhibition of sulphate-reducing bacteria by metal sulphide formation in bioremediation of acid mine drainage. Environ Toxicol 17:40-48

Utgikar VP, Tabak HH, Haines JR, Govind R (2003) Quantification of toxic and inhibitory impact of copper and zinc on mixed cultures of sulfate-reducing bacteria. Biotechnol Bioeng 82:306-312

Vega-López A, Amora-Lazcano E, López-López E, Terrón O, ProalNágera JB (2007) Toxic effects of zinc on anaerobic microbiota from Zimapán Reservoir (Mexico). Anaerobe 13:65-73

Verma A, Dua R, Singh A, Bishnoi NR (2015) Biogenic sulfides for sequestration of $\mathrm{Cr}(\mathrm{VI}), \mathrm{COD}$ and sulfate from synthetic wastewater. Water Sci 29:19-25

White C, Dennis JS, Gadd GM (2003) A mathematical process model for cadmium precipitation by sulfate-reducing bacterial biofilms. Biodegradation 14:139-151

Willis CL, Cummings JH, Neale G, Gibson GR (1997) Nutritional aspects of dissimilatory sulfate reduction in the human large intestine. Curr Microbiol 35:294-298

Willow MA, Cohen RRH (2003) pH, dissolved oxygen, and adsorption effects on metal removal in anaerobic bioreactors. J Environ Qual 32:1212-1221 